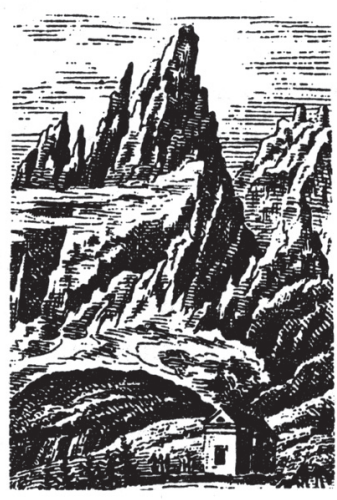

Ewa Kolbuszewska

ORCID: 0000-0001-8703-1042

Uniwersytet Wrocławski

ewa.kolbuszewska@uwr.edu.pl

DOI: $10.19195 / 2084-4107.12 .13$

\title{
Cepry w górach. Turystyka masowa w krzywym zwierciadle (do lat siedemdziesiątych XX wieku)
}

Słowa-klucze: turysta, turystyka masowa, Tatry, Zakopane, ochrona przyrody Keywords: tourist, mass tourism, Tatras, Zakopane, nature protection

\section{Lowlanders in the mountains: A satirising view of mass tourism (until the 1970s)}

\section{Summary}

The sense of tourism lies in disinterested move from place to place for purposes relating to entertainment and exploration. In 1841 Thomas Cook organised a train excursion for 570 people in England and thus began the era of collective tourism. In the 20th century mass tourism became passive tourism. Such tourism does not require a lot of physical effort and the only thing tourists expect is appropriate transport, access to interesting sights and infrastructure that will satisfy their 
basic needs. Another characteristic of this type of tourism is the fact that participants do not have to organise their journeys themselves. It should be stressed, however, that in the 20 th century tourism became a substantial social movement of great economic significance. Its essence can be defined in a concise formula: "maximum satisfaction with minimum personal effort". As a result of economic changes in the interwar period, tourism became increasingly democratic, popular and accessible to the masses. The development of passive tourism, which as time goes by transforms itself into largescale mass tourism, can best be followed in the case of tourism in the Tatras. The Tatras, which were "discovered" quite late, became a tourist destination for an increasing number of people already at the turn of the 20th century. The number of tourists grew rapidly in the second half of the 19th century. However, the first visitors to the Podhale region and Zakopane were not very well prepared for excursions in the mountains. Such visitors were referred by the term "ceper" or lowlander, from the beginning having negative and, if not contemptuous then certainly disrespectful connotations. Its etymology is not known. The ignorance of non-highlanders, i.e. their naivety and inexperience, was quite irritating for the simple and intellectually uncomplicated, but "sharp" and cunning local inhabitants of the Podhale region. That is why lowlanders were often laughed at and ridiculed by them. Throughout the 20th century interesting sociological and cultural changes happened consistently and systematically in tourism. Initially tourists were representatives of the wealthier classes, but owing to the development of collective tourism tourists began to come from many other groups in society. As a result there emerged the problem of anthropogenic impact on the natural environment, which in turn increased the significance of the problem of nature protection.

\section{W wydawanym w latach 1933-1939 zarysie encyklopedycznym Świat $i$ życie} pod hasłem „turystyka” czytamy, iż na to pojęcie składają się dwa prądy, dwa odmienne kierunki rozwojowe: „Różnice najlepiej podkreśla podział na turystykę bierną i czynną. Podział ten przeprowadzany jest ze względu na ustosunkowanie się samego turysty do uprawianej przez niego turystyki"". Autor hasła podkreślał, że czynnikiem decydującym jest w tym wypadku charakter i rodzaj samej turystyki. Turystyka bierna ma służyć głównie odczuciu przyjemności i zawierać w sobie cel poznawczy. Już zresztą znacznie wcześniej Mark Twain w Przygodach Tomka Sawyera wprowadził rozróżnienie na podróżowanie-pracę i podróżowanie dla przyjemności. Podczas gdy ta pierwsza jest zawsze mniej czy bardziej przykrym obowiązkiem, to druga, choć sporo pod względem finansowym człowieka kosztuje, może dostarczyć wielu pozytywnych emocji i przeżyć ${ }^{2}$ Turystyka bierna nie wymaga od uprawiających ją dużego wysiłku fizycznego, a turysta oczekuje tylko zapewnienia mu odpowiedniego transportu, ułatwienia dostępu do obiektów ciekawych i godnych zobaczenia oraz zagwarantowania infrastruktury, która zaspokoi jego podstawowe potrzeby bytowe.

Ułatwienie jest hasłem turystyki biernej. Turysta musi odbyć wycieczkę w warunkach najdogodniejszych, najłatwiejszych, z najmniejszym

${ }^{1}$ K. Narkiewicz-Jodko, Turystyka, [w:] Świat i życie. Zarys encyklopedyczny współczesnej wiedzy i kultury, red. Z. Łempicki, t. 4, Lwów 1939, szp. 1154.

2 „Wielu bogatych dżentelmenów w Anglii tłucze się powozem, zaprzężonym w czwórkę koni, dwadzieścia lub trzydzieści mil w upale - bo ta przyjemność kosztuje ich dużo pieniędzy, ale niechby im kto kazał robić to samo za wynagrodzeniem, poczęliby to uważać za pracę i woleliby z niej zrezygnować" - M. Twain, Przygody Tomka Sawyera, przeł. K. Piotrowski, Warszawa 1933, s. 20.

Góry - Literatura - Kultura 12, 2018

(C) for this edition by CNS 
wysiłkiem osobistym, w atmosferze spokoju, beztroski, przyjemności i wypoczynku. Warunkiem jedynym i wystarczającym do wprawiania turystyki biernej są odpowiednie środki pieniężne ${ }^{3}$.

Lawinowo rosnące zainteresowanie przestrzenią górską swoimi początkami sięga drugiej połowy XIX wieku i trwa do dziś. Podkreślić jednak należy, że wiek XX doprowadził do tego, że turystyka urosła do wymiarów sporego ruchu społecznego o dużym znaczeniu ekonomicznym. Jego istotę można zamknąć w dość lapidarne stwierdzenie: „Maksimum zadowolenia przy minimum wysiłku osobistego" $"$.

Wraz z narastającymi w okresie międzywojennym zmianami ekonomicznymi turystyka ulegała coraz większej demokratyzacji, spopularyzowaniu i umasowieniu. Najlepiej rozwój turystyki biernej, która w miarę upływu czasu przekształciła się w wielką i masową, można prześledzić na przykładzie turystyki tatrzańskiej. Tatry bezkonkurencyjnie i bezwarunkowo wygrywają bowiem pod względem atrakcyjności z innymi regionami kraju. Odkryte dość późno — na przełomie XIX i XX wieku - stały się swoistą mekką. Pierwsi przybywający na Podhale i do Zakopanego goście nie byli jednak zbyt dobrze przygotowani do górskich eskapad. Właśnie na takich przybyszów z nizin znaleziono określenie „ceper”5, mające zresztą od samego początku negatywne, może nie pogardliwe, ale lekceważące, pejoratywne zabarwienie. Jego etymologia nie jest znana. Ignorancja nie-górali, czyli ich naiwność, niedoświadczenie, były dość irytujące dla prostych i nieskomplikowanych intelektualnie, ale „cwanych” oraz przebiegłych rdzennych mieszkańców Podhala, dlatego też wielokrotnie „ceper” stawał się przedmiotem ich żartów i kpin. Zjawisko to ilustrowała chociażby scenka, czy raczej humoreska, zamieszczona w 1903 roku na łamach „Liberum Veto”. Oto młody, świeżo namaszczony na przewodnika góral wybiera się po raz pierwszy z gronem warszawskich pań do Morskiego Oka, stary ojciec udziela mu na drogę dobrej rady, by nie wdawał się w bliższą konfidencję z żadną z kobiet, bo może okazać się ona flądrą, kocmołuchem, a dla takiej szkoda jego urody ${ }^{6}$.

Napływający na Podhale turyści w miarę upływu czasu coraz bardziej przyczyniali się do rozwoju ekonomicznego tego regionu. Równocześnie wymuszali poprawę standardów bytowych, w jakich będą przebywać. Jalu Kurek w specyficznej pod względem literackim Księdze Tatr wtórej pisał, że we wsi Zakopane studnie sąsiadowały z ustępami i gnojowiskami; jednocześnie zastanawiając się nad fenomenem turystyki, sam udzielał sobie odpowiedzi na pytanie o jej sens: „Po co tu przyjeżdżają ludzie? Mówi się: z dolin, choćby była mowa o równinach, bo wszystko, co leży niżej od gór, to doły. Przybywają tu, aby łazić po skałach, aby podziwiać skały, aby oddychać skalnym powietrzem"7. W podobny ton uderzał

${ }^{3}$ K. Narkiewicz-Jodko, op. cit., szp. 1155.

${ }^{4}$ Ibidem, szp. 1156.

5 Z. Radwańska-Paryska, W.H. Paryski, Wielka encyklopedia tatrzańska, Poronin 1995, s. 136.

6 J. Jedlicz, Ojcowskie rady, „Liberum Veto” 1903, nr 15, s. 64.

7 J. Kurek, Księga Tatr wtóra, Kraków 1978, s. 23. 
Rafał Malczewski w felietonie Od cepra do wariata, pisząc: „Ceper, czyli człowiek nizin, ponadto nieco płony i niezguła, gdy po raz pierwszy przybędzie do Zakopanego, przeżyje wiele wstrząsów i niespodzianek, raczej nieprzyjemnych" "; szybko jednak przystosuje się do atmosfery Podhala i ostatecznie na tyle w niej rozsmakuje, że będzie tu wielokrotnie powracać.

Pojawienie się najpierw w Alpach, a później w nieporównywalnie mniejszych Tatrach ogromnej rzeszy nieprzystosowanych i nieprzygotowanych do turystyki ludzi stało się wielkim problemem logistycznym. Masowa turystyka wymagała bowiem zorganizowania i zapewnienia gościom odpowiedniej infrastruktury, czyli: rozwoju dróg, kolei, wyznaczenia i oznakowania szlaków górskich, budowy szałasów, bud i szaletów, wyznaczenia miejsc postojowych, profesjonalnego przewodnictwa czy wreszcie, ale to już znacznie później, budowy kolejek i wyciągów. Zadowoleni turyści korzystający z proponowanych im udogodnień i dobrodziejstw chętnie płacili (i to słono!) za oferowane usługi i atrakcje, czyli — innymi słowy - za przyjemności. Wychodząc naprzeciwko oczekiwaniu „,ceprów”, czy też może łagodniej „gości”, w 1873 roku utworzono Polskie Towarzystwo Tatrzańskie, które rok później, mając na uwadze uprzystępnienie gór, co zresztą zostało zapisane w statucie organizacji, założyło pierwsze biuro obsługi turystów, nazwane pierwotnie Kasynem TT. W 1922 roku zadomowiło się w drewnianym „Dworcu Tatrzańskim”, pełniąc przez wiele lat funkcję ośrodka informacyjno-kulturalnego dla wszystkich przybywających do Zakopanego'.

Rozwój turystyki masowej na dużą skalę datuje się w Europie od pierwszej połowy XIX wieku. Za jej ojca uważa się Thomasa Cooka, który w 1841 roku perfekcyjnie zorganizował wycieczkę kolejową dla 570 osób na „,meeting abstynencki”. Zdobyte doświadczenia wykorzystał, zakładając profesjonalne biuro podróży. W Polsce turystyka na szerszą skalę rozwinęła się znacznie później. Trzeba bowiem pamiętać, że do 1873 roku w Tatrach nikt nie budował ani nie znakował ścieżek. Pierwszy drukowany przewodnik po Tatrach napisany w języku polskim został wydany w 1860 roku, natomiast kolej żelazna zawitała na Podhale w latach siedemdziesiątych XIX wieku (1874 - otwarcie linii Kraków-Chabówka, 1889 — połączenie Chabówki z Zakopanem), co zaowocowało ogromnym ożywieniem ruchu turystycznego, silną antropopresją na góry i zwiększonym przepływem „dutków”, czyli pieniędzy, przez wieś Zakopane, nazywane przez złośliwców „podgiewontowym potworkiem” lub „Giewontowem”. Nie powodowało to jednak szybkich radykalniejszych zmian na korzyść w wyglądzie wsi: „Stoją pseudoluksusowe pensjonaty na śmiesznie małych parcelkach, gołych i bezsensownych, w otoczeniu najwyższego niechlujstwa: śmietników, cuchnących potoków, brud-

8 R. Malczewski, Od cepra do wariata, Warszawa 1939, s. 12.

9 Zob. Z. Radwańska-Paryska, W.H. Paryski, Dworzec Tatrzański, [w:] eidem, Wielka encyklopedia tatrzańska..., s. 234-235; Polskie Towarzystwo Tatrzańskie, [w:] Z. Radwańska-Paryska, W.H. Paryski, Wielka encyklopedia tatrzańska..., s. 948-952; W. Krygowski, Zarys dziejów turystyki górskiej, Warszawa 1973, s. 38-44. 
nych sklepików" - pisał Malczewski ${ }^{10}$. W innym felietonie dodawał ironicznie: „Zakopane bowiem to typowy wiek dziewiętnasty, restauracje i kawiarnie - epoka zbójników, drogi — czas wypraw krzyżowych, Tatry — przedpotopowy okres, reszta - Biskupin, osada bagienna" "11.

Kronika towarzyska rocznika „Wierchy” z 1927 roku szerzej rozpisywała się o ceprach odwiedzających to wyjątkowe miejsce na ziemi: „Większość gości przeważnie szuka wrażeń »wysokogórskich« na Równi Krupowej, »weranduje« najchętniej na werandzie Trzaski, podziwia »szczyty« z okien »Tatrzańskiej«, słucha »szmeru strumieni górskich« na »plaży« u Karpowicza albo w »Higienicznej «"12. Był to katalog wszystkich zakopiańskich knajp i restauracji, na dobre już wpisanych w przestrzeń miasta i pełniących funkcje rekreacyjno-rozrywkowo-kulturalne. Dla wielu turystów i wczasowiczów Zakopane pozostawało miejscem docelowym, w obrębie którego mogli korzystać z wielu przyjemności.

Licznym przyjezdnym — jak Ferdynandowi Goetlowi — z tego okresu pozostały jednak wspomnienia negatywne. Z perspektywy czasu opisywał on koszmarny najazd na miasto samochodów i motocykli, współzawodniczących przy akompaniamencie wyjących $w$ wyścigu tatrzańskim silników ${ }^{13}$. Wzmianka o letnich rajdach automobilistów pojawiła się też we wspomnianej Kronice towarzyskiej Zakopanego za 1927 rok: „Odbyły się też w sezonie letnim rajdy automobilowe Polskiego Klubu Automobilistów, wyścig górski na szosie do Morskiego Oka, rajd Klubu Automobilowego Krakowskiego, który się odbył 14 sierpnia br., zmobilizował około 500 samochodów i motocykli. Zakopane huczało, »ryczało $z$ radości, że tylu ludzi tak się tu spieszy — »ozon « z powietrza zawoniał benzyną, ale to wszystko było bardzo miłe..."14.

Dla polskiego turysty musiał być więc szokiem zastany po drugiej stronie Tatr widok pustych słowackich kurortów, w których: „Mimo asfaltów, luksusów, paprykowanych ścieżek w parkach gości w nienaskiej części Tatr jest dziwnie mało"15. My natomiast zaskakiwaliśmy sąsiadów naszym podtatrzańskim Biskupinem, albowiem: „Nasz potworek czaruje od razu. Wszystkim. Niespodzianką, przygodą, rozległością, nonsensem i psychicznym klimatem" — pisał sarkastycznie Malczewski ${ }^{16}$.

W latach poprzedzających wojnę z wolna, lecz konsekwentnie i systematycznie dokonywały się w turystyce ciekawe zmiany socjologiczno-kulturowe. Proces ten zauważył Walery Goetel, brat Ferdynanda, pisząc, że początkowo zwiedzali Tatry reprezentanci warstw zamożniejszych, a następnie na szlakach pojawiła się młodzież i robotnicy. Nie zmieniało to jednak faktu, że dla większości społeczeń-

10 R. Malczewski, op. cit., s. 29.

11 Ibidem, s. 88-89.

12 K. Brudzińska, Kronika zakopiańska, „Wierchy” 5, 1927, s. 196-197, cyt. za: Osobliwości i sensacje tatrzańskie, oprac. J. Kolbuszewski, Kraków 1977, s. 143.

13 F. Goetel, Tatry, Londyn 1953, s. 44.

14 K. Brudzińska, op. cit., s. 143-144.

15 R. Malczewski, op. cit., s. 89-90.

16 Ibidem. 
stwa turystyka była z różnych względów mało dostępna ${ }^{17}$. Jednocześnie trzeba odnotować narodziny nowej koncepcji ideologicznej turystyki masowej. Ideologia ta narodziła się w PTT i wyrosła z chęci ,pomnażania Tatr, polegającej na: [...] umożliwieniu zwiedzania Tatr szerokim sferom ludzi niezamożnych, zwłaszcza młodzieży". Zakładano, że dzięki takim zabiegom, jak organizowanie wycieczek zbiorowych, urządzeniu domów turystycznych ,zaistnieją Tatry dla tysięcy oczu i serc, dla których przedtem nie istniały"18.

Narastająca w miarę upływu czasu liczba ,użytkowników” Tatr z jednej strony wymuszała zapewnienie im komfortu i bezpieczeństwa, z drugiej — zwiększała obawy o przyszłość polskich gór. Nad problemem tym zastanawiał się inicjator ruchu ochrony przyrody Jan Gwalbert Pawlikowski:

Problemem, który się tutaj nasuwa, jest to problem wynalezienia sposobu pogodzenia dwóch na pozór sprzecznych tendencji — uprzystępniania i zachowania... Jeżeli w gruncie rzeczy urok Tatr jest podstawą ich wartości ekonomicznej jako miejsca wędrówki „dólskich” przybyszów, to zniszczenie tego uroku musi w dalszej przyszłości niweczyć ich wartość materialną ${ }^{19}$.

W tym wypadku myślenie ekologiczne stawało w opozycji do myślenia ekonomicznego, a dylematu tego nie udało się rozwiązać do dziś. Przybliżenie do Tatr masowej turystyki mogło bowiem grozić skutkami nieodwracalnymi. Różne groteskowe pomysły związane z zagospodarowywaniem gór przywoływał Władysław Krygowski, pisząc:

nie wszyscy zdawali sobie sprawę, że uprzystępnianie jest nosicielem zawiązku niebezpieczeństwa, odsuniętego jeszcze wówczas w czasie, lecz zagrażającego kiedyś przyrodzie. Na uroczystościach w górach i na hucznych wycieczkach wiwatowali nieraz wtedy strzałami z moździeży, na szczytach wznoszono krzyże, w dolinach wmurowywano tablice dla uczczenia czyjejś pamięci. Nie raził nikogo wtedy projekt budowy wielkiego posągu Matki Boskiej na szczycie Babiej Góry, przeciwnie — było to w stylu wieku i w duchu ówczesnego stosunku człowieka do gór. Można by widzieć w tej epoce okres kolonizacyjnego stosunku do egzotycznej krainy gór, które człowiek chciał sobie podporządkować ${ }^{20}$.

Z obawą w przyszłość spoglądał także Jerzy Wawrzyniec Żuławski, który pisał: „Będziemy uciekać, kryć się w najdalsze doliny, aż tłum [...] »turystów« cho-

17 W. Goetel, O właściwa drogę turystyki w Tatrach, „Wierchy” 35, 1966, s. 21.

18 J.G. Pawlikowski, Memoriat w sprawie ochrony Tatr, [w:] Wybór pism. „O lice ziemi”, Warszawa 1939, cyt. za: W. Krygowski, op. cit., s. 77.

19 Fragment wypowiedzi na czterdziestolecie Towarzystwa Tatrzańskiego w 1913 roku, cyt. za: W. Krygowski, op. cit., s. 74.

${ }^{20}$ Ibidem, s. 73-74. 
dzących luksusowymi ścieżkami do »luksusowych « schronisk, jeżdżących kolejką »dla widoku« lub po prostu przez snobizm, zwycięży nas w końcu"21.

Te obawy nie były bezpodstawne, albowiem nieomal od początku XX wieku rodziły się pomysły zagospodarowania gór na potrzeby turystyki masowej. Wiele projektowanych przedsięwzięć udało się udaremnić z powodu ich niedorzeczności, co jednak nie było jednoznaczne z całkowitym ich zaniechaniem. Do takich chybionych pomysłów zaliczyć można „ceprostradę” — drogę przecinającą zbocze Miedzianego. Z kolei w celu uczczenia pamięci zasłużonych dla odzyskania Morskiego Oka planowano budowlę kapliczki z różnokolorowymi szybkami w oknach i portretami bohaterów. Wymyślna harfa zbudowana na tle olbrzymich bloków, zaopatrzona w metalowe struny targane wiatrem, miała wygrywać melodie. W ścianie Kościelca lub na usypanej na Morskim Oku wysepce zamierzano pochować zwłoki Juliusza Słowackiego. W górski krajobraz wprowadzono drabiny, łańcuchy, poręcze i różnorakie udogodnienia dla ceprów, nie zważając na to, że to jest sprzeczne z naturą. Najbardziej jednak kuriozalny pomysł zaprezentował inżynier Walerian Dzieślewski, który pragnął wybudować kolejkę zębatą prowadzącą przez Halę Gąsienicową, Liliowe i dochodzącą na szczyt Świnicy.

W okresie przedwojennym najczęściej podejmowanym tematem był natomiast projekt budowy kolejki linowej na Kasprowy Wierch, mający licznych zwolenników i przeciwników. Pomysł ten doczekał się ostatecznie realizacji, ale pełnej aprobaty nigdy nie otrzymał, aczkolwiek liczni przybysze do Zakopanego i narciarze byli zachwyceni:

Publiczność zakopiańska [...] przeparła budowę kolejki linowej na Kasprowy Wierch. W ruch poszły argumenty społeczne, których jęto teraz używać, gdy chodziło o każdą inwestycję w górach. Tatry dla wszystkich! — wołano, nie zważając na zatłoczenie gór zaborczą i niewybredną gawiedzią, która wypierała z Tatr ciszę i przyrodę, a zniszczenia zauważyć nie mogła, rada sobie samej22

— ironizował Ferdynand Goetel. Znacznie dalej z ostrą krytyką całego przedsięwzięcia poszedł syn Jana Gwalberta - Michał Pawlikowski, który w studium Góry $i$ człowiek pisał ogromnie oburzony i zdegustowany poczynionymi na Kasprowym Wierchu inwestycjami:

hańba kultury polskiej, na usprawiedliwienie społeczeństwa polskiego dokonana z pogwałceniem jego woli i prawa. Ze wszystkich szczytów Tatr polskich widoczny w sercu ich hotel na Kasprowym, [...] z ,szosami” do niego prowadzącymi, gdzie wygrzewają się opasłe (przeważnie starozakonne) burżuje, a skąd w noc sylwestrową nadaje radio zapite głosy uczestników wesołej zabawy. Urocza, cicha, pełna limb Dolina Kaspro-

21 J.W. Żuławski, Na wschodniej ścianie Łomnicy (2 VIII 1935), „Taternik” 22, 1937/1938, nr 3, s. 60, cyt. za: Osobliwości i sensacje tatrzańskie, s. 422.

${ }^{22}$ F. Goetel, op. cit., s. 67. 
wa, do której takie oto spadają spusty, zlewy wszystkich nieczystości, poprzecinana pasmami korczunku [!] stumetrowej szerokości i zniszczona bezpowrotnie. Liny błyszczące, w słońcu, jak szramy przez twarz widać na tle wierchu na dziesięć kilometrów ${ }^{23}$.

Ironiczny ton pobrzmiewał także w wierszu Noc na Kasprowym Henryka Zbierzchowskiego, który z wyraźną kpiną naśmiewał się z technicznych dobrodziejstw, z jakich mógł w górach skorzystać typowy ceper, „zdobywszy” Kasprowy Wierch:

Noc już zapadła czarniejsza od piekła,

Przez Goryczkową gdym doszedł do szczytu,

Więc z końcem ścieżki, co spod stóp uciekła,

Lęk mnie ogarnął i pustka niebytu.

I nagle w mroku, tuż pod szczytem blisko,

Błysnęło światło, jak nadzieja złota -

Oto kolejki stacja i schronisko,

Za chwilę wchodzę już w gościnne wrota.

Jakaż to rozkosz po wspinaczki męce,

Obok przepaści, gdzie śmierć czyha blada,

$\mathrm{Na}$ wysokości metrów dwóch tysięcy

Znaleźć nad głową schron, gdy noc zapada.

Jakaż to radość z pewnej ubikacji

Pociągając sobie żelazny sznurek

I po herbacie i smacznej kolacji -

W białą się pościel położyć jak nurek ${ }^{24}$.

Uwagę na nadmierną eksploatację Tatr i ich zadeptywanie zwrócił już w 1903 roku Władysław Orkan w zabawnym skeczu wydrukowanym na łamach „Liberum Veto”. Na ten literacki drobiazg zatytułowany Pomruk gór albo rozmowa składał się wyimaginowany dialog Świnicy i Zawratu. Pierwsza z gór uskarżała się drugiej, że dotąd setki gnid (w domyśle turystów) po jej głowie łaziło, a teraz będą dojeżdżać wagonami. Odpowiedź Zawratu nie rozwiewała złudzeń i brzmiała pesymistycznie:

Oh, ci ludzie! Obłażą i mnie od lat... Pnie się to, aż śmiesznie patrzeć... Czego to szuka? Idzie się potem na dół pochwalić, że był na mojej głowie.

23 M. Pawlikowski, Góry i człowiek, Warszawa 1939, wkładka 14-15 [autorski komentarz do nieliczbowanych ilustracji].

${ }^{24}$ H. Zbierzchowski, Noc na Kasprowym, cyt. za: Osobliwości i sensacje tatrzańskie, Kraków 1977, s. 155. 
To byle wsza potrafi [...]. Jak on hań Giewont wytrzyma? On najbliższy... Już mu pod pazuchą wnetki usadowią... [...] Dziwne te stworzenia... jak mrówce dokuczliwe ${ }^{25}$.

Smutne refleksje Zawratu dopełnia Świnica: „A jak się to puszy, gdy mi stanie na głowie na zadnich swoich nóżkach..."26.

Podobny motyw rozmowy gór wykorzystał mało znany jako poeta, za to znakomity taternik Maciej Zajączkowski w wierszu Bunt olbrzymów:

Stary Mięgusz rzekł te słowa

do małżonki swej Cubryny:

„Pęka głowa,

Gdy widzę jak bez przyczyny

Ludzie łażą po nas jak wszy"27.

Oba przywołane utwory połączył wspólny mianownik — niechęć do fali turystów zalewającej góry, które nie są w stanie same się obronić. Nadmierna ich eksploatacja dokonywana przez ,gnidy” i ,wszy”, czyli ceprów, mogła w przyszłości grozić wielką katastrofą ekologiczną.

Lata wojenne (1939-1945) przystopowały rozwój turystyki tatrzańskiej. Wraz z nadejściem wolności romantyczne i witalne przesłanie Wincentego Pola: „W góry, w góry, miły bracie” zastąpiono hasłami bardziej demagogicznymi, typu: „Tylko poznawszy i pokochawszy swój kraj, można owocnie dla niego pracować”, „Góry nasze, góry dla wszystkich”, „Otwarcie gór dla tysiąca oczu i serc” itp.

W wydanej w 1957 roku broszurze Na bezdrożach myśli tatrzańskiej. O właściwe zasady turystyki ekolog Zbigniew Wierzbicki, traktując skalne Podhale jako skarbiec ogólnonarodowy, podjął próbę stworzenia filozoficznych podstaw nowożytnej turystyki. Krytykując patologie współczesnej turystyki, sformułował jej krytyczny obraz jako fenomenu chaotycznego, hałaśliwego i antyekologicznego. Jeden z rozdziałów jego pracy nosił tytuł Turystyka w krzywym zwierciadle i przynosił jej wielce nieżyczliwy obraz. Wśród ludzi uprawiających tę formę działalności dominował bowiem element nieprzygotowania do górskich wędrówek, czyli przypadkowość, przy pozbawieniu wrażliwości na piękno. Nieprofesjonalnie zorganizowane grupy przyjeżdżały w góry bez odpowiedniego przygotowania i ekwipunku: ,z walizkami, w miejskim spacerowym stroju, w obuwiu na wysokich obcasach itp. Rozpowszechniły się one po wojnie nagminnie, ponieważ stanowią najłatwiejszy, chociaż bynajmniej nie najlepszy, sposób na wydatkowanie funduszy na tzw. cele socjalne" 28 . W celu lepszego zilustrowania tego zjawiska Wierzbicki opisał jedną z przypadkowych wycieczek zmierzających w kierunku Morskiego Oka: zatrzymuje się ona przy Wodogrzmotach Mickiewicza i z trzy-

\footnotetext{
25 W. Orkan, Pomruk Gór albo rozmowa, „Liberum Veto” 1903, nr 3, s. 49-50.

26 Ibidem.

27 M. Zajączkowski, Bunt olbrzymów, cyt. za: Osobliwości i sensacje tatrzańskie, s. 151.

28 Z.T. Wierzbicki, Na bezdrożach myśli tatrzańskiej, Poznań 1957, s. 11.
} 
dziestoosobowego autokaru, by je zobaczyć, wysiadają tylko dwie osoby. Pozostali zasłaniają się zmęczeniem, albowiem wcześniej „,zaliczyli” już: spływ Dunajcem, Gubałówkę, a przed nimi jeszcze Morskie Oko. „Sposób zorganizowania tych wycieczek u nas urąga zdrowemu rozsądkowi i w każdym razie nie może dać tych przeżyć i wrażeń, które powinna dawać prawdziwa turystyka" 29 — konstatował Wierzbicki.

Podobne obserwacje poczynił Tadeusz Staich — przewodnik, wybitny znawca Podhala i jego kultury. W zbiorze opowiadań Góry wołaja zamieścił on sporo uwag i spostrzeżeń dotyczących funkcjonowania powojennej turystyki:

Kierownicy akcji socjalnej w zakładach pracy organizują coraz częściej zbiorowe wycieczki dwu i jednodniowe, nawet majówki i parogodzinne wyprawy. Kolejarze i kierowcy samochodów przewożą ludzi do Zakopanego jak towar, jak „drobnicę”. Są tygodnie, że wydaje się, jakby jakiś szaleniec stanął na czele ludzkiego mrowia i krzyknął za Anczycem: „Hej, za mną w Tatry, w ziemię czarów. Na strome szczyty gór...”. Co prawda z tymi ,stromymi szczytami” było nieco gorzej, jako że ludzkie mrowie, załadowane w sześć wagonów, przyjeżdżało na stację w Poroninie - i tu najczęściej kończyły się wysokogórskie zapędy. Zwiedzało się muzeum, potem spacer na Galicową Grapę, a potem z powrotem do pociągu i sapiąca lokomotywa wywoziła stłoczonych ludzi na wysoki próg dworca w Zakopanem. Tutaj, po podróży na Gubałówkę i zwiedzaniu miasta, udawało się czasem zdobyć bilety do kolejki na Kasprowy [... $]^{30}$.

W przewodnickich opowiadaniach osnutych na tle autentycznych wydarzeń Staich z empatią opisywał scenki obyczajowe graniczące z groteską: wycieczkę orkiestry ochotniczej straży pożarnej ubranej w galowe mundury i niosącej sprzęt muzyczny; grupę chłopów reprezentujących Związek Samopomocy Chłopskiej, taszczących walizki i drewniane kuferki; czterdziestu hutników z Szopienic podróżujących wraz z beczkami z piwem i dużym wozem ciężarowym, zmierzających do Morskiego Oka...

To usytuowane w głębi Tatr piękne jezioro zostało uznane za jedną z największych atrakcji turystycznych. Stała linia PKS uruchomiona na asfaltowej drodze prowadzącej bezpośrednio do Morskiego Oka znacznie przyczyniła się do jego spopularyzowania. „Natłok autobusów, samochodów ciężarowych, osobowych i motocykli na drodze do Morskiego Oka okazał się tak wielki, że długi wąż pojazdów motorowych rozciągał się w pogodne dni letnie wzdłuż drogi na kilka kilometrów”; równie tragicznie wyglądał powrót: „odbywał się on w wolnym posuwaniu się naprzód zatłoczonych na szosie pojazdów w hałasie motorów i zaduchu spalin"31. Otoczenie jeziora porównywano do lunaparku, ośmieszano fotografów naciągających turystów na pamiątkowe zdjęcie z „Janosikiem” ubranym w olbrzy-

29 Ibidem, s. 12.

30 T. Staich, Góry wołają. Opowiadania przewodnickie, wyd. 2, Poronin 1994, s. 12.

31 W. Goetel, Z walki o piękno Tatr, „Wierchy” 30, 1961, s. 50. 
mią „czapę” i ,zbójnicki” strój, a także krytykowano kakofonię dźwięków i hałas w otoczeniu chronionym, będącym rezerwatem ścisłym. Wszelkie zastrzeżenia przyrodników ostrzegających przed szkodliwością tych zjawisk na przypływających masach pseudoturystów nie robiły większego wrażenia. Niektórzy nawet sugerowali, by w tym wyjątkowym zakątku natury górskiej wybudować szalety czy stację benzynową.

Upowszechnienie masowej turystyki dokonujące się w XX wieku na coraz większą skalę oceniane było bardzo negatywnie przez naukowców, a przede wszystkim przez propagatorów idei ochrony przyrody. W latach siedemdziesiątych na łamach „Taternika” w ciekawy sposób wypowiedział się na ten temat Jan Alfred Szczepański, który w artykule O ochronie przyrody — bez złudzeń uznał, iż deglomeracja Tatr jest koniecznością. Gór nie można przed nikim zamknąć, powinny one być zarezerwowane dla wszystkich turystów indywidualnych: „,bo taternik i turysta powinni mieć prawo swobodnego poruszania się po Tatrach"32. To wycieczki zbiorowe doprowadzają do dewastacji przyrody, wobec czego należy im położyć kres, dać zakaz wstępu z pewnymi wyjątkami. Dopuszczone mogą być wycieczki autokarowe do Morskiego Oka, zwiedzanie Doliny Kościeliskiej i wjazd kolejką na Kasprowy Wierch,

Ale na tym koniec. Dla wycieczek zbiorowych, dla wielkich rajdów od schroniska do schroniska, dla szaleńczego w swej lekkomyślności pałętania się przedszkolaków po Giewontach, a młodzieży szkolnej po Świnicach i Rysach — nie powinno być absolutnie miejsca. Absolutnie więc bez wyjątku ${ }^{33}$.

Dodawał też, iż należy walczyć z pchaniem się w Tatry motocyklistów, uczniów, harcerzy, wycieczek gromadnych i stadnych, gdyż jest to antyturystyka propagowana pod oszukańczym szyldem popierania turystyki masowej. Ta bowiem w pewnym momencie wymknęła się spod kontroli. Antropopresja na góry narastała z roku na rok. Turystyczne autobusy zmajoryzowały turystykę pieszą. Do tego wszystkiego dochodziły liczne rajdy czy imprezy polegające na przejściu długich tras turystycznych (najczęściej kilkudniowe). Wszyscy uczestnicy wędrowali jedną trasą albo dużymi grupami do wspólnego celu. W Tatrach i na Podtatrzu najbardziej popularny był Rajd Leninowski (odbywany do 1989 roku). Błędnie traktowano te imprezy jako nie tylko upowszechnienie turystyki, lecz także wprowadzenie i przyzwyczajenie ich uczestników do samodzielnych wędrówek po górach, nie bacząc na to, że do świadomego wspinania się na szczyty i właściwego kontemplowania ich piękna trzeba długo dojrzewać. Nie bez obawy więc prawie pięćdziesiąt lat temu Szczepański zastanawiał się, czy w 2000 roku Tatry będą ocalone zarówno dla przyrody, jak i prawdziwych turystów.

W październiku 2017 na łamach „Gazety Wyborczej” ukazał się krótki wywiad z Markiem Kamińskim — podróżnikiem i filozofem, który zwierzył się, że

32 J.A. Szczepański, O ochronie przyrody — bez złudzeń, „Taternik” 45, 1969, nr 1, s. 3.

33 Ibidem. 
Tatry są dla niego rezerwuarem niezbędnej dla życia energii i że czuje się za nie odpowiedzialny. Dlatego warto przytoczyć tu jego słowa:

Stracimy coś ważnego, jeżeli będziemy próbować komercjalizować Tatry, budować kolejne hotele, ściągać turystów za wszelką cenę [...]. Powtórzę: Zostawmy je w spokoju! [...] Tatry można zdeptać, zaśmiecić — tylko co później? ${ }^{34}$

\section{Bibliografia}

Goetel F., Tatry, Londyn 1953.

Goetel W., O właściwa drogę turystyki w Tatrach, „Wierchy” 35, 1966, s. 21.

Goetel W., Z walki o piękno Tatr, „Wierchy” 30, 1961, s. 50.

Jedlicz J., Ojcowskie rady, „Liberum Veto” 1903, nr 15, s. 64.

Kamiński M., Bez natury człowiek umiera. Rozmowa Dominika Szczepańskiego z..., „Gazeta Wyborcza" 12.10.2017.

Krygowski W., Zarys dziejów turystyki górskiej, Warszawa 1973.

Kurek J., Księga Tatr wtóra, Kraków 1978.

Malczewski R., Od cepra do wariata, Warszawa 1939.

Narkiewicz-Jodko K., Turystyka, [w:] Świat i życie. Zarys encyklopedyczny współczesnej wiedzy i kultury, red. Z. Łempicki, t. 4, Lwów 1939, szp. 1154.

Orkan W., Pomruk Gór albo rozmowa, „Liberum Veto” 1903, nr 3, s. 49-50.

Osobliwości i sensacje tatrzańskie, oprac. J. Kolbuszewski, Kraków 1977.

Pawlikowski M., Góry i człowiek, Warszawa 1939.

Radwańska-Paryska Z., Paryski W.H., Wielka encyklopedia tatrzańska, Poronin 1995.

Staich T., Góry wołają. Opowiadania przewodnickie, wyd. 2, Poronin 1994.

Szczepański J.A., O ochronie przyrody — bez złudzeń, „Taternik” 45, 1969, nr 1, s. 1-3.

Twain M., Przygody Tomka Sawyera, przeł. K. Piotrowski, Warszawa 1933.

Wierzbicki Z.T., Na bezdrożach myśli tatrzańskiej, Poznań 1957.

34 M. Kamiński, Bez natury człowiek umiera. Rozmowa Dominika Szczepańskiego z..., „Gazeta Wyborcza” 12.10.2017. 